\title{
The B7 family molecules in oral squamous cell carcinoma: a systematic review. Part II: B7-1, B7-2, B7-H2, B7-H3, B7-H4, B7-H5 (VISTA), B7-H6 and B7-H7
}

\author{
Anna Starzyńska ${ }^{1}$, Aleksandra Sejda ${ }^{2}$, Łukasz Adamski ${ }^{1}$, Paulina Adamska ${ }^{1}$, Rafał Pęksa $^{3}$, \\ Monika Sakowicz-Burkiewicz ${ }^{4}$, Piotr Wychowański ${ }^{5}$, Barbara A. Jereczek-Fossa ${ }^{6,7}$ \\ ${ }^{1}$ Department of Oral Surgery, Medical University of Gdansk, Gdansk, Poland \\ 2Department of Pathomorphology, University of Warmia and Mazury, Olsztyn, Poland \\ ${ }^{3}$ Department of Pathomorphology, Medical University of Gdansk, Gdansk, Poland \\ ${ }^{4}$ Department of Molecular Medicine, Medical University of Gdansk, Gdansk, Poland \\ ${ }^{5}$ Department of Oral Surgery, Medical University of Warsaw, Warsaw, Poland \\ ${ }^{6}$ Division of Radiotherapy, IEO European Institute of Oncology, IRCCS, Milan, Italy \\ 'Department of Oncology and Hemato-oncology, University of Milan, Milan, Italy
}

Adv Dermatol Allergol DOI: https://doi.org/10.5114/ada.2020.98523

\begin{abstract}
Introduction: The most common malignant neoplasm of the oral cavity is squamous cell carcinoma. It accounts for over $95 \%$ of malignant lesions in this area and is characterised by rapid spread and distant metastases.

Aim: To collect and review the data on B7 family proteins as prognostic factors in oral squamous cell carcinoma and to describe their role in aggressive disease progression.

Material and methods: A systematic review of the literature about B7-1, B7-2, B7-H2, B7-H3, B7-H4, B7-H5 (VISTA), B7-H6 and B7-H7, was carried out, following the Preferred Reporting Items for Systematic Reviews and MetaAnalyses (PRISMA) guidelines. 9 articles published before 22 May 2020 were included in the systematic review. Results: The biggest study group consisted of 201 patients and the smallest - 40 patients. B7-1, B7- H3, B7-H4, $\mathrm{B} 7-\mathrm{H} 5, \mathrm{~B} 7-\mathrm{H} 6$ and $\mathrm{B} 7-\mathrm{H} 7$ protein expressions were prognostic factors. Overall survival was significantly associated with B7-H3, B7-H5, B7-H6 and B7-H7. Immunohistochemistry was the diagnostic method used in all the studies. Conclusions: The data presented indicate the complexity of cellular and molecular processes related to the formation, development and invasion of oral cancer. Mutations in genes encoding the B7 family and changes in the B7 protein pathway may affect the prognosis of survival in patients with oral squamous cell carcinoma.
\end{abstract}

Key words: squamous cell carcinoma, oral cavity, B7 antigens.

\section{Introduction}

The most common malignant neoplasm of the oral cavity is squamous cell carcinoma (oral squamous cell carcinoma-OSCC), which accounts for over $95 \%$ of these lesions. The lesions are more common in men over 60 years of age. Oral cancer is characterised by rapid spread and distant metastases. The outcome is still unsatisfactory. Identification of new markers may be of use in prevention, diagnostics, prognosis and choice of a targeted therapy [1-4].

The B7/CD28 family proteins are involved in the regulation of the immune response by limiting both time and strength of the inflammatory response $[5,6]$. The B7 family includes proteins: B7-1, B7-2, B7-H2, B7-DC, B7-H1, B7-H2, B7-H3, B7-H4, B7-H5, B7-H6 and B7-H7. The group of receptors includes proteins: CD28, CTLA-4, ICOS, PD-1 and TMIGD2 (Table 1). They are potential objects of research when introducing new therapeutic agents [7-9].

\footnotetext{
Aim

The aim of this paper was to systematically review the literature and to summarise correlations between B7 family proteins and prognosis in OSCC.
}

Address for correspondence: Anna Starzyńska, Department of Oral Surgery, Medical University of Gdansk, 7 Dębinki St, $80-211$ Gdansk, Poland, phone: +48 5834915 71, e-mail: ast@gumed.edu.pl Received: 2.07.2020, accepted: 3.08.2020. 
Table 1. B7/CD28 family

\begin{tabular}{|c|c|}
\hline Ligands (B7) & Receptors (CD28) \\
\hline $\begin{array}{l}\text { B7-1 (cluster of differentiation 80/CD80/B7/B7.1/BB1/CD28LG/ } \\
\text { CD28LG1/LAB7) }\end{array}$ & $\begin{array}{l}\text { CD28 (cluster of differentiation 28) } \\
\text { CTLA-4 (cytotoxic T-lymphocyte-associated protein 4/cluster } \\
\text { of differentiation 152/CD152) } \\
\text { PD-L1 (programmed cell death } 1 \text { ligand 1/cluster of } \\
\text { differentiation 274/B7-H1/CD274/PDCD1LG1/B7H1/B7-H/ } \\
\text { PDCD1L1/PDCD1LG1/PDL1) }\end{array}$ \\
\hline $\begin{array}{l}\text { B7-2 (cluster of differentiation 86/CD86/B7.2/B70/CD28LG2/ } \\
\text { LAB72) }\end{array}$ & $\begin{array}{l}\text { CD28 (cluster of differentiation 28) } \\
\text { CTLA-4 (cytotoxic T-lymphocyte-associated protein 4/cluster } \\
\text { of differentiation 152/CD152) }\end{array}$ \\
\hline $\begin{array}{l}\text { B7-DC (programmed cell death } 1 \text { ligand 2/cluster of differentiation } \\
\text { 273/CD273/PDCD1LG2/B7DC/Btdc/PDCD1L2/PDL2/bA574F11.2) }\end{array}$ & $\begin{array}{l}\text { PD-1 (cluster of differentiation 279/CD279) } \\
\text { RGMb (repulsive guidance molecule B) }\end{array}$ \\
\hline $\begin{array}{l}\text { B7-H1 (programmed cell death } 1 \text { ligand 1/cluster of differentiation } \\
\text { 274/PD-L1/CD274/PDCD1LG1/B7H1/B7-H/PDCD1L1/PDCD1LG1/PDL1) }\end{array}$ & $\begin{array}{l}\text { PD-1 (cluster of differentiation 279/CD279) } \\
\text { B7-1 (cluster of differentiation 80/CD80/B7/B7.1/BB1/CD28LG/ } \\
\text { CD28LG1/LAB7) }\end{array}$ \\
\hline $\begin{array}{l}\text { B7-H2 (cluster of differentiation 275/CD275/ICOSLG/B7H2/B7RP-1/ } \\
\text { B7RP1/GL50/ICOS-L/ICOSL/LICOS/inducible T cell co-stimulator } \\
\text { ligand) }\end{array}$ & $\begin{array}{l}\text { ICOS (inducible T cell co-stimulator/cluster of differentiation } \\
278 / C D 278 \text { ) }\end{array}$ \\
\hline $\begin{array}{l}\text { B7-H3 (cluster of differentiation 276/CD276/4lg-B7-H3/B7H3/ } \\
\text { B7RP-2) }\end{array}$ & Unknown \\
\hline $\begin{array}{l}\text { B7-H4 (B7x/B7s/VTCN1/B7H4/B7S1/B7X/B7h.5/PRO1291/VCTN1/ } \\
\text { V-set domain containing T cell activation inhibitor 1) }\end{array}$ & Unknown \\
\hline $\begin{array}{l}\text { B7-H5 (V-domain Ig suppressor of T cell activation/VISTA/VSIR/ } \\
\text { B7H5/GI24/PP2135/SISP1/DD1alpha/C10orf54/chromosome } 10 \\
\text { open reading frame 54/PD-1H/V-set immunoregulatory receptor) }\end{array}$ & Unknown \\
\hline B7-H6 (NCR3LG1) & $\begin{array}{l}\text { NKp30 (natural cytotoxicity triggering receptor 3/NCTR3/ } \\
\text { CD337/cluster of differentiation 337) }\end{array}$ \\
\hline B7-H7 (BTNL2/BTL-II/HHLA2/B7H7/B7-H5/B7y) & $\begin{array}{l}\text { CD28H (transmembrane and immunoglobulin domain } \\
\text { containing 2/TMIGD2/IGPR-1) }\end{array}$ \\
\hline
\end{tabular}

\section{Material and methods}

For this review, a systematic search of the literature was conducted in the PubMed, Web of Science, Scopus, Embase, Cochrane Library, and Google Scholar databases to identify papers containing data about B7 family proteins in OSCC. The PRISMA guidelines (Preferred Reporting Items for Systematic Reviews and Meta-Analyses) guidelines were used [10].

PICO for study characteristics was used (P - patient/ population/problem; I - intervention/exposure; C - comparison; O - outcome):

P: at least 10 patients with primary OSCC;

I: protein expression evaluation;

C: not required;

$\mathrm{O}$ : B7 family proteins as prognostic factors in OSCC - only B7-1, B7-2, B7-H2, B7-H3, B7-H4, B7-H5 (VISTA), $\mathrm{B} 7-\mathrm{H} 6$ and $\mathrm{B} 7-\mathrm{H} 7$.

Inclusion criteria for papers were as follows: at least 10 patients with primary OSCC, B7 protein expression evaluation, study conducted only on humans, in the English language, prospective and retrospective studies, clinical studies and immunohistochemical evaluation of B7 protein. Articles were excluded if specimens derived from OSCC recurrences (not primary tumours), research was conducted on cell lines, was not conducted on humans, the study group consisted of less than 10 patients, non-B7 family protein expression was evaluated or the study was not in English. Duplicate records as well as letters and papers that did not contain significant information were also excluded.

A retrospective analysis of articles on the B7 family proteins as risk factors in OSCC published from 2012 to 22 May 2020 was performed. Key words: "B7 family", "CTLA-4/B7-1/B7-2 pathway", "B7-H2/CD275/ICOSLG/ B7H2/B7RP-1/B7RP1/GL50/ICOS-L/ICOSL/LICOS/inducible T cell co-stimulator ligand", "B7-H3/CD276/4lg-B7H3/B7H3/B7RP-2", "B7-H4/B7x/B7s/VTCN1/B7H4/B7S1/ B7X/B7h.5/PRO1291/VCTN1/V-set domain containing T cell activation inhibitor 1", "B7-H5/V-domain Ig suppressor of T cell activation/VISTA/VSIR/B7H5/GI24/PP2135/ SISP1/DD1alpha/C10orf54/chromosome 10 open reading frame 54/PD-1H/V-set immunoregulatory receptor", "B7-H6/NCR3LG1", "B7-H7/BTNL2/BTL-II/HHLA2/B7H7/ B7-H5/B7y" and oral "cancer/OSCC/oral squamous cell carcinoma" were used. Articles were screened and sorted based on titles and abstracts. Then, articles were evaluat- 
ed for eligibility. Data extracted from those records were analysed in detail. The following pieces of information were collected: total patient number, occurrence of B7 family alterations in OSCC, correlations with age, gender, grading, primary tumour size (T stage), nodal metastases (N stage), staging, prognostic significance and diagnostic methods (immunohistochemistry and other methods). For randomized studies, the Cochrane Collaboration tool was used [11] and the methodological index for nonrandomized studies (MINORS) was used [12]. The ideal global score for non-comparative studies is 16 and for comparative is 24 [12].

\section{Statistical analysis}

Statistical analysis was carried out using the Statistica 13.3 (StatSoft Inc. Tulsa, United States), licensed by the the Medical University of Gdansk.

\section{Results}

In the first step of selection 261 references were identified. 248 records were selected after the exclusion of the duplicates. Eventually, 9 articles were included in the systematic review (Figure 1) [13-21]. Three studies addressed B7-1 protein, one article was on B7-2, 2 studies involved $\mathrm{B} 7-\mathrm{H} 3$, one article was on $\mathrm{B} 7-\mathrm{H} 4$, one study involved $\mathrm{B} 7-\mathrm{H} 5$, one study involved $\mathrm{B} 7-\mathrm{H} 6$ and one involved $\mathrm{B} 7-\mathrm{H} 7$ (some articles were duplicated). Currently, B7-H2 protein is not described in OSCC. The first identified study was published in 2012. Table 2 shows the articles included in the analysis [13-21].

Observational studies were the most commonly presented papers. There were no randomized controlled trials. $88.89 \%$ were retrospective $(n=8)$ and $11.11 \%$ of the studies were prospective $(n=1)$. Studies were mostly cohort-based $(88.99 \%, n=8)$, rarely cross-sectional $(2.23 \%$, $n=1$ ) (Tables 3 and 4).

The biggest study group consisted of 201 patients and the smallest -40 patients. In total, 893 patients (excluding duplicates) were analysed in the studies. The following proteins have been described: B7-1, B7-2, B7-H3, B7-H4, B7-H5, B7-H6 and B7-H7 (Table 2). In all tested samples, the expression of proteins was found by testing proteins $\mathrm{B} 7-\mathrm{H} 4$ and $\mathrm{B} 7-\mathrm{H} 5$. The occurrence of protein expression was as follows: B7-1-55\%; B7-2 - 57.5\%; B7H3 - about 67\%, B7-H4 - 100\%; B7-H5 - 100\%, B7-H6 - 48\% and B7-H7 - no data. Only B7-1 expression was correlated with age [13]. Grading was correlated with B7-H3 [17], B7-H4 [18] and B7-H5 [19] protein expression. Primary tumour size (T stage) was associated with $\mathrm{B} 7-\mathrm{H} 3$ protein [16]. Metastases in lymph nodes were correlated with B7-1 [14], B7-H3 [17], B7-H4 [18] and B7-H5 protein expression [19]. Staging was correlated with B7-1, B7-2 [14] and B7-H3 protein expression [17]. B7-1, B7-H3, B7$\mathrm{H} 4, \mathrm{~B} 7-\mathrm{H} 5, \mathrm{~B} 7-\mathrm{H} 6$ and $\mathrm{B} 7-\mathrm{H} 7$ protein expressions were prognostic factors. Overall survival was significantly

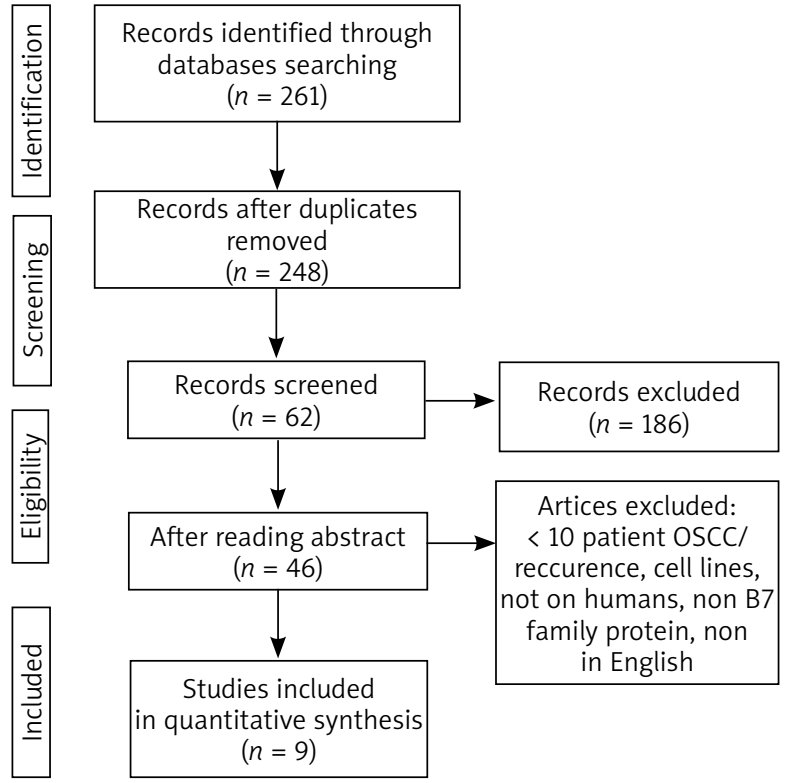

Figure 1. PRISMA flow diagram of study selection

associated with B7-H3 [17], B7-H5 [19], B7-H6 [20] and B7-H7 [21]. Disease-free survival was correlated with B7$\mathrm{H} 6$ protein [56]. Poor survival was related to B7-H4 [18]. Relapse-free survival was significantly associated with B7-1 [13]. Immunohistochemistry was used as a diagnostic method in all the studies.

\section{Discussion}

\section{B7 protein family and the receptors}

\section{B7-1/B7-2/CTLA-4 pathway}

B7-1 protein is a type I membrane protein encoded by the CD80 gene on chromosome 3 (locus 3q13.33). B7-1 has two domains: immunoglobulin constant-like domain (IgC; extracellular) and the variable-like domain (IgV), required for receptor binding. This protein is expressed on the surface of monocytes, macrophages, mast cells, activated $B$ lymphocytes, podocytes, fibroblasts, antigenpresenting and dendritic cells. T cells are co-stimulated and activated by B7-1 protein. The function of the CD80 protein is to stimulate the signal that activates $T$ lymphocytes. This is necessary for their survival. B7-1 protein binds to CD28, CTLA-4 and PD-L1 receptors. The binding of the CD80 protein to the CD28 receptor enables autoregulation and intercellular connection. The binding to CTLA-4 receptor allows reduction of regulation and cellular dissociation. B7.1 protein plays a role in the induction of T cell anti-tumour immunity $[8,9,13,15,22]$. The presence of the B7-1 protein expression has been demonstrated in numerous malignancies, such as human hepatocellular cancer [22], thyroid cancer [23], bladder cancer [24] and pancreatic cancer [25]. Chaux et al. revealed that 
Table 2. B7 family genetic alterations in oral squamous cell carcinomas: a review of current studies

\begin{tabular}{|c|c|c|c|c|c|c|c|c|c|c|c|c|}
\hline \multirow[t]{2}{*}{ No } & \multirow[t]{2}{*}{ Reference } & \multirow{2}{*}{$\begin{array}{l}\text { Study } \\
\text { type }\end{array}$} & \multirow{2}{*}{$\begin{array}{c}\text { Total patient } \\
\text { number }\end{array}$} & \multirow{2}{*}{$\begin{array}{c}\text { Occurrence } \\
\text { of protein } \\
\text { expression } \\
n \text { patients } \\
(\%)\end{array}$} & \multicolumn{7}{|c|}{ Correlations } & \multirow{2}{*}{$\begin{aligned} \frac{n}{0} \\
\frac{0}{+} \\
\sum^{0}\end{aligned}$} \\
\hline & & & & & Age & Gender & Grading & $\begin{array}{c}\text { Primary } \\
\text { tumour size } \\
\text { (T stage) }\end{array}$ & $\begin{array}{c}\text { Nodal } \\
\text { metastases } \\
\text { (N stage) }\end{array}$ & Staging & $\begin{array}{l}\text { Prognostic } \\
\text { significance }\end{array}$ & \\
\hline \multicolumn{13}{|c|}{ B7-1: } \\
\hline 1 & $\begin{array}{l}\text { Rah et al., } \\
2018 \text { [13] }\end{array}$ & $\mathrm{O}, \mathrm{R}, \mathrm{C}$ & 60 & No data & $p=0.016$ & $\begin{array}{c}\text { NS } \\
p=0.521\end{array}$ & NE & $\begin{array}{c}\text { NS } \\
p=0.889\end{array}$ & $\begin{array}{c}\text { NS } \\
p=0.233\end{array}$ & $\begin{array}{c}\text { NS } \\
p=0.655\end{array}$ & $\begin{array}{l}\text { ReFS }-S \\
p=0.038 \\
\text { DFS - NS } \\
p=0.156\end{array}$ & $\mathrm{IHC}$ \\
\hline 2 & $\begin{array}{l}\text { Zhang et al., } \\
2017 \text { [14] }\end{array}$ & $\mathrm{O}, \mathrm{P}, \mathrm{C}$ & 40 & $22(55 \%)$ & $\mathrm{NE}$ & NE & $\begin{array}{c}\text { NS } \\
p>0.050\end{array}$ & NE & $\begin{array}{c}\mathrm{S} \\
p=0.036\end{array}$ & $\begin{array}{c}\mathrm{S} \\
p=0.020\end{array}$ & $\mathrm{NE}$ & $\mathrm{IHC}$ \\
\hline 3 & $\begin{array}{l}\text { Dayan et al., } \\
2012 \text { [15] }\end{array}$ & $\mathrm{O}, \mathrm{R}, \mathrm{C}$ & 64 & No data & $\mathrm{NE}$ & $\mathrm{NE}$ & $\mathrm{NE}$ & $\mathrm{NE}$ & $\mathrm{NE}$ & NE & $\mathrm{NE}$ & $\mathrm{IHC}$ \\
\hline \multicolumn{13}{|c|}{ B7-2: } \\
\hline 1 & $\begin{array}{l}\text { Zhang et al., } \\
2017 \text { [14] }\end{array}$ & $\mathrm{O}, \mathrm{P}, \mathrm{C}$ & 40 & $23(57.5 \%)$ & NE & NE & $\begin{array}{c}\mathrm{NS} \\
p>0.050\end{array}$ & NE & $\begin{array}{c}\mathrm{S} \\
p=0.024\end{array}$ & $\begin{array}{c}\mathrm{S} \\
p=0.041\end{array}$ & NE & $\mathrm{IHC}$ \\
\hline \multicolumn{13}{|c|}{ B7-H2: } \\
\hline \multicolumn{13}{|c|}{$\mathrm{NE}$} \\
\hline \multicolumn{13}{|c|}{ B7-H3: } \\
\hline 1 & $\begin{array}{l}\text { Chen et al., } \\
2015 \text { [16] }\end{array}$ & $\mathrm{O}, \mathrm{R}, \mathrm{C}$ & 72 & $48(67 \%)$ & $\begin{array}{c}\text { NS } \\
p>0.050\end{array}$ & $\begin{array}{c}\text { NS } \\
p>0.050\end{array}$ & $\mathrm{NE}$ & $\begin{array}{c}\mathrm{S} \\
p=0.0001\end{array}$ & $\begin{array}{c}\text { NS } \\
p>0.050\end{array}$ & $\begin{array}{c}\mathrm{S} \\
p=0.004\end{array}$ & $\begin{array}{c}\text { OS }-S \\
p=0.005\end{array}$ & $\mathrm{IHC}$ \\
\hline 2 & $\begin{array}{l}\text { Zhang et al., } \\
2015 \text { [17] }\end{array}$ & $\mathrm{R}, \mathrm{CSS}$ & 76 & 51 (67.1\%) & $\mathrm{NE}$ & $\mathrm{NE}$ & $\begin{array}{c}\mathrm{S} \\
p=0.011\end{array}$ & $\begin{array}{c}\text { NS } \\
p=0.135\end{array}$ & $\begin{array}{c}\mathrm{S} \\
p=0.026\end{array}$ & $\begin{array}{c}\text { NS } \\
p=0.135\end{array}$ & $\mathrm{NE}$ & $\mathrm{IHC}$ \\
\hline \multicolumn{13}{|c|}{ B7-H4: } \\
\hline 1 & $\begin{array}{l}\text { Wu et al., } \\
2016 \text { [18] }\end{array}$ & $\mathrm{O}, \mathrm{R}, \mathrm{C}$ & $\begin{array}{l}165 \text { primary } \\
\text { OSCC } \\
12 \text { recurrent } \\
\text { OSCC } \\
10 \text { OSCC with } \\
\text { pre-surgical } \\
\text { radiotherapy } \\
17 \text { OSCC with } \\
\text { pre-surgical } \\
\text { chemotherapy }\end{array}$ & 165 (100\%) & NE & NE & $\begin{array}{c}\mathrm{S} \\
p<0.010\end{array}$ & $\begin{array}{c}\text { NS } \\
p=0.0683\end{array}$ & $\begin{array}{c}\mathrm{S} \\
p<0.050\end{array}$ & $\begin{array}{c}\text { NS } \\
p=0.068\end{array}$ & $\begin{array}{c}\text { PS }-\mathrm{S} \\
p<0.050\end{array}$ & $\mathrm{IHC}$ \\
\hline \multicolumn{13}{|c|}{ B7-H5 (VISTA): } \\
\hline 1 & $\begin{array}{l}\text { Wu et al., } \\
2017 \text { [19] }\end{array}$ & $\mathrm{O}, \mathrm{R}, \mathrm{C}$ & $\begin{array}{l}165 \text { primary } \\
\text { OSCC } \\
12 \text { recurrent } \\
\text { OSC } \\
10 \text { OSCC with } \\
\text { pre-surgical } \\
\text { radiotherapy } \\
17 \text { OSCC with } \\
\text { pre-surgical } \\
\text { chemotherapy }\end{array}$ & 165 (100\%) & NE & NE & $\begin{array}{c}\mathrm{NS} \\
p>0.050\end{array}$ & $\begin{array}{c}\text { NS } \\
p>0.050\end{array}$ & $\begin{array}{c}\mathrm{S} \\
p<0.050\end{array}$ & $\begin{array}{c}\text { NS } \\
p>0.050\end{array}$ & $\begin{array}{c}\text { OS }-\mathrm{S} \\
p=0.036\end{array}$ & $\mathrm{IHC}$ \\
\hline \multicolumn{13}{|c|}{ B7-H6: } \\
\hline 1 & $\begin{array}{l}\text { Wang et al., } \\
2017 \text { [20] }\end{array}$ & $\mathrm{O}, \mathrm{R}, \mathrm{C}$ & 50 & $24(48 \%)$ & $\begin{array}{c}\text { NS } \\
p>0.050\end{array}$ & $\begin{array}{c}\mathrm{NS} \\
p>0.050\end{array}$ & $\begin{array}{c}\mathrm{S} \\
p=0.0186\end{array}$ & $\begin{array}{c}\text { NS } \\
p>0.050\end{array}$ & $\begin{array}{c}\text { NS } \\
p>0.05\end{array}$ & $\begin{array}{c}\text { NS } \\
p=0.460\end{array}$ & $\begin{array}{c}\text { DFS }-S \\
p=0.005 \\
\text { OS }-S \\
p=0.007\end{array}$ & $\mathrm{IHC}$ \\
\hline \multicolumn{13}{|c|}{ B7-H7: } \\
\hline & $\begin{array}{l}\text { Xiao et al., } \\
2019 \text { [21] }\end{array}$ & $\mathrm{O}, \mathrm{R}, \mathrm{C}$ & 201 & No data & NE & NE & NS & NS & NS & NE & $\begin{array}{c}\text { OS }-\mathrm{S} \\
p=0.031\end{array}$ & $\mathrm{IHC}$ \\
\hline
\end{tabular}


Table 3. Results of MINORS for non-comparative studies

\begin{tabular}{|c|c|c|c|c|c|c|c|c|c|c|}
\hline & \multirow[t]{2}{*}{ Reference } & \multicolumn{9}{|c|}{ MINORS for non-comparative studies } \\
\hline & & 1 & 2 & 3 & 4 & 5 & 6 & 7 & 8 & Score \\
\hline 1 & Zhang et al., 2017 [14] & 2 & 2 & 2 & 1 & 0 & 1 & 2 & 0 & 10 \\
\hline 2 & Dayan et al., 2012 [15] & 2 & 2 & 2 & 2 & 0 & 1 & 2 & 0 & 11 \\
\hline
\end{tabular}

1-a clearly stated aim, 2 - inclusion of consecutive patients, 3 - prospective data collection, 4 - endpoints appropriate to the aim of the study, 5 - unbiased assessment of the study endpoint, 6 -follow-up period appropriate to the aim of the study, 7 -loss to follow up less than $5 \%$, 8 - prospective calculation of the study size; score: 0 - not reported, 1 -reported but inadequate, 2 -reported and adequate; the ideal global score for comparative studies is 16.

Table 4. Results of MINORS for comparative studies

\begin{tabular}{|c|c|c|c|c|c|c|c|c|c|c|c|c|c|c|}
\hline \multirow[t]{2}{*}{ No. } & \multirow[t]{2}{*}{ Reference } & \multicolumn{13}{|c|}{ MINORS for comparative studies } \\
\hline & & 1 & 2 & 3 & 4 & 5 & 6 & 7 & 8 & 9 & 10 & 11 & 12 & Score \\
\hline 1 & Xiao et al., 2019 [21] & 2 & 1 & 2 & 2 & 1 & 1 & 2 & 0 & 1 & 1 & 1 & 2 & 16 \\
\hline 2 & Rah et al., 2018 [13] & 2 & 2 & 2 & 2 & 2 & 1 & 2 & 0 & 2 & 2 & 2 & 2 & 21 \\
\hline 3 & Wang et al., 2017 [20] & 2 & 1 & 2 & 2 & 0 & 1 & 2 & 0 & 1 & 1 & 1 & 2 & 15 \\
\hline 4 & Wu et al., 2017 [19] & 2 & 2 & 2 & 2 & 0 & 1 & 2 & 0 & 1 & 1 & 1 & 2 & 16 \\
\hline 5 & Wu et al., 2016 [18] & 2 & 2 & 2 & 2 & 0 & 1 & 2 & 0 & 1 & 1 & 1 & 2 & 16 \\
\hline 6 & Chen et al., 2015 [16] & 2 & 0 & 2 & 2 & 0 & 1 & 2 & 0 & 1 & 1 & 1 & 2 & 14 \\
\hline 7 & Zhang et al., 2015 [17] & 2 & 2 & 2 & 0 & 0 & 1 & 2 & 0 & 2 & 2 & 2 & 2 & 17 \\
\hline
\end{tabular}

1 - a clearly stated aim, 2 - inclusion of consecutive patients, 3 - prospective data collection, 4 - endpoints appropriate to the aim of the study, 5 - unbiased assessment of the study endpoint, 6 - follow-up period appropriate to the aim of the study, 7 - loss to follow up less than $5 \%$, 8 - prospective calculation of the study size, 9 - an adequate control group, 10 - contemporary groups, 11 - baseline equivalence of groups, 12 - adequate statistical analyses; score: 0 - not reported, 1 -reported but inadequate, 2 -reported and adequate; the ideal global score for comparative studies is 24.

in colorectal cancer, expression of the B7-1 and B7-2 molecules were not found. As a consequence, the immune system does not recognise cancer cells as antigenic $[26,27]$. Wang et al. demonstrated that the B7-1 negative status was a prognostic factor for poor disease-specific survival in pancreatic carcinoma [25]. The literature documenting B7-1 protein in OSCC is limited. CD80 protein in OSCC was first reported in 2012 by Dayan et al. [15]. According to some studies, the percentage of common B7-1 protein range was 55\% [14]. B7-1 protein expression correlated with age, recurrence, relapse-free survival [13], stage, and nodal metastases in OSCC [14].

B7-2 is a type I membrane protein encoded by the CD86 gene on chromosome 3 (locus 3q13.33). This protein is expressed on the surface of antigen-presenting cells, T cells, B lymphocytes, dendritic cells, monocytes, macrophages and mast cells. It is the source of the costimulatory signal. The B7-2 protein has genes parallel to $B 7-1$ ligand in $27 \%$. It activates T lymphocytes and is necessary for their survival. B7-2 protein binds to CD28 and CTLA-4 receptors. The binding of the CD86 protein to the CD28 receptor enables autoregulation and intercellular connection. The binding to CTLA receptor allows to reduce regulation and cellular dissociation. B7.1 protein plays a role in the induction of $\mathrm{T}$ cell anti-tumour immunity $[7,14,22]$. The presence of the B7-2 protein expression has been demonstrated in human hepatocellular carcinoma [27] and thyroid carcinoma [23]. B7-2 protein in OSCC was reported in 2017 by Zhang et al. In the study mentioned, the percentage of common B7-2 protein was
$57.5 \%$. This protein expression correlated with stage and nodal metastases [14].

CD28 is a co-stimulatory receptor of B7-1 and B7-2 molecules. CD28 is encoded by the CD28 gene on chromosome 2 (locus 2q33.2). This protein consists of the immunoglobulin variable-like domain (IgV; extracellular), transmembrane domain, stalk domain and a cytoplasmic domain. CD28 receptor is found on naive T lymphocytes, plasma cells, NK and NKT cells (natural killers T cells). This molecule is a receptor of B7-1 and B7-2 ligands. This protein stimulates $T$ cell receptor (TCR). CD28 molecule is associated with $T$ cell activation, proliferation, tolerance and survival. This protein provides a signal for production of various interleukins (e.g. interleukin 2) and amplifies the immune system response. Activated T cells stimulate B lymphocytes to produce antibodies. The pathways associated with CTLA-4 and ICOS cannot be activated without the induction of the CD28 receptor [8, 28-30]. CD28 protein affects apoptosis via $\mathrm{Bcl}-\mathrm{xL}$ (anti-apoptotic protein - B-cell lymphoma-extra large). Lymphocytes are not subject to programmed death [31]. Activation of CD28 causes the induction of transcription and/or stabilization of cytokine mRNAs: IL-4, IL-5, IL-8, IL-13, interferon $\gamma$ (IFN- $\gamma$ ) and tumour necrosis factor $\alpha$ (TNF- $\alpha$ ). The lack of co-stimulation by CD28 leads to the anergy of clonal lymphocytes. Anergy means a lack of reaction by the body's defence mechanisms to foreign substances [29, 30].

CTLA-4 is a protein receptor of B7-1 and B7-2 molecules and down-regulates T lymphocytes activity. CTLA-4 is encoded by the CTLA-4 gene located on chromosome 
2 in locus 2q33.2. The CTLA-4 has genes parallel to the CD28 receptor in $26.9 \%$ [8, 32, 33]. This protein consists of the immunoglobulin variable-like domain (IgV; extracellular), transmembrane domain, stalk domain and a cytoplasmic domain. CTLA-4 receptor is found on T lymphocytes, dendritic cells, B lymphocytes, NK cells, NKT cells, monocytes, granulocytes and fibroblasts. Roles of CTLA-4 include inhibition of $\mathrm{T}$ cell activation and their response by blocking AKT protein (serine-threonine protein kinase = protein kinase $\mathrm{B}$ ). CTLA protein skips phosphatidyl-inositol 3-kinase signalling pathway. Most CTLA-4 molecules are found in lysosomes. First, binding of B7-1 and B7-2 ligands to the CD28 receptor occurs. It activates the lymphocyte. Then, the CTLA-4 receptor is transported to the cell membrane and expressed. Activation of CTLA-4 provides a stimulus that can trigger feedback to inhibit lymphocyte activation. The presence of the CTLA-4 receptor on the tumour cell membrane avoids a specific immune response [8]. Excessive expression of the gene encoding the CTLA-4 protein may be associated with: Ewing's sarcoma, laryngeal, hepatocellular, prostate, lung, breast, cervical [6, 32, 34-37], nasopharyngeal [38], and head and neck carcinoma [39]. In OSCC studies, the CTLA-4 gene polymorphism was detected via polymerase chain reaction-restriction fragment length polymorphism (PCRRFLP). Single nucleotide polymorphisms (SNPS): -1722C/T, $-1661 \mathrm{~A} / \mathrm{G},-1661 \mathrm{G} / \mathrm{G},-1661 \mathrm{~A} / \mathrm{A}$ and $-318 \mathrm{C} / \mathrm{T}$ in the promoter region, 49A/G in exon 1, and CT60A/G in the 3'untranslated region (UTR) were assessed in patients with tobacco-related carcinoma. Genotypes: -1722CC, -1661AG and CT60AA are more frequent in patients with OSCC. The polymorphism of the CTLA-4 1661-genotype alone and in combination with other polymorphisms may be a risk factor for oral cancer [30, 32]. In Moreira et al. study, no statistical association was found between overall survival and expression level of CTLA-4 protein [40].

\section{B7-H2 and ICOS}

B7-H2 is encoded by the ICOSLG gene on chromosome 21 (locus 21p12). The $\mathrm{B} 7-\mathrm{H} 2$ protein has genes parallel to B7-1 ligand in 27\%. It binds to ICOS. B7-H2 was found on B lymphocytes, T cells, monocytes, mast cells, dendritic cells, macrophages, endothelial cells, epithelial cells, fibroblasts and osteoblasts. It plays an important role in cell-to-cell signalling, immune response, cell proliferation, functions of effector and Treg lymphocytes. CD275 can promote T lymphocyte production of cytokines, including IL-10, IL-4, IL-5, IL-7, IL-10, and interferon- $\gamma$. High levels of $\mathrm{B} 7-\mathrm{H} 2$ protein have been demonstrated in patients with colon cancer $[8,41]$, but have not been examined in OSCC.

ICOS is a co-stimulatory molecule and receptor of B7$\mathrm{H} 2$ protein. This molecule is encoded by the ICOS gene on chromosome 2 (locus 2q33.2). The ICOS has genes parallel to CD28 receptor in $24.1 \%$ [8, 29, 30]. This protein consists of the immunoglobulin variable-like domain (IgV; extracellular), transmembrane domain, stalk domain and a cytoplasmic domain [8]. ICOS protein is expressed on activated $\mathrm{T}$ and $\mathrm{B}$ lymphocytes and binds to $\mathrm{B} 7-\mathrm{H} 2$ protein. It plays an important role in cell-to-cell signalling, immune response and cell proliferation. ICOS is upregulated on activated $T$ lymphocytes. The gene polymorphism of /COS was studied in positions $+637 \mathrm{~A} / \mathrm{C}$ and $+1599 \mathrm{C} / \mathrm{T}[8,29,30]$.

\section{$B 7-H 3$}

B7-H3 protein is a type I membrane protein encoded by the CD276 gene on chromosome 15 (locus 15q24.1). The B7-H3 protein has genes parallel to B7-1 ligand in 29\%. It has two domains: IgV and IgC. B7-H3 molecule connects to the previously unknown receptor [7, 8, 42]. TLT-2 (TREML2) may be a binding partner for B7-H3. It may affect the growth of CD4 (T helper lymphocytes) and CD8 (T cytotoxic lymphocytes) $T$ cells proliferation, and selectively increases the secretion of IFF. B7-H3 protein is found on activated dendritic cells, monocytes, macrophages, T, B and NK lymphocytes, epithelial cells, fibroblasts and osteoblasts. $\mathrm{B} 7-\mathrm{H} 3$ molecule is a protein that controls the immune system. There are studies suggesting stimulating effects (by T lymphocytes) as well as inhibiting the immune system (by NK cells). The B7-H3 protein induces selective production of interferon- $\gamma$. Inhibition of the immune system can occur through NFAT (nuclear factor of activated T cells), NF-кB (nuclear factor $\kappa$-light-chain-enhancer of activated $B$ cells), and AP-1 (activator protein 1) factors. This affects the TCR, which regulates gene transcription [7, 8, 43]. The presence of the B7-H3 protein expression has been demonstrated in neuroblastoma, lung cancer [44], pancreatic cancer [45], breast cancer [46], ovarian cancer [47], endometrial cancer [48], prostate cancer [49], renal cancer [50], gastric cancer [51], colorectal cancer [52], gallbladder cancer [53], hepatocellular cancer [54], and head and neck cancer [55]. It results in poor outcome in patients with these types of cancer [7]. Potential anti-B7-H3 therapy seems to be beneficial for the treatment of central nervous system tumours. The expression of $\mathrm{B} 7-\mathrm{H} 3$ can be associated with a decrease in the number of active lymphocytes, a large tumour size and the presence of metastases [56]. $\mathrm{B} 7-\mathrm{H} 3$ protein level in OSCC was higher than in normal mucosa [17]. In OSCC, B7-H3 protein expression was associated with grade [17], tumour size [16], nodal metastases [17], and overall survival [16]. B7-H3 was correlated with poor overall survival [16]. Protein expression was not associated with location of cancer, distant metastases, recurrence, alcohol consumption, betel chewing or smoking [16].

\section{B7-H4}

B7-H4 protein is a type I membrane protein encoded by the B7-H4 gene on chromosome 1 (locus 1q13.1). The $\mathrm{B} 7-\mathrm{H} 4$ protein has genes parallel to $\mathrm{B} 7-1$ ligand in 
21\%. B7-H4 has two domains: IgC and IgV. Like B7-H3, $\mathrm{B} 7-\mathrm{H} 4$ is present in most tissues and is a control protein of the immune system. This protein was found on dendritic cells, monocytes, macrophages and mesenchymal stem cells. However, the protein expression itself is very limited [7, 8, 57]. B7-H4 inhibits the proliferation of CD4 $T$ cells, resulting in suppressed production of cytokines (IL-2), and the proliferation of CD8 upon TCR/CD28 ligation. It binds to the receptor only on activated $T$ cells, which can be a factor differentiating from other B7/CD28 family proteins. This suggests that the $\mathrm{B} 7-\mathrm{H} 4$ pathway may be another system that inhibits the cellular response of T lymphocytes. B7-H4 expression is correlated with an increased expression of IL-6 [7, 58, 59]. The presence of the $\mathrm{B} 7-\mathrm{H} 4$ protein expression has been demonstrated in lung cancer [60], ovarian cancer [61], cervical cancer [62], oesophagus cancer [63], gastric cancer [64], colorectal cancer [65], pancreatic cancer [66], prostate cancer [49], thyroid cancer [67] and melanoma [68]. $\mathrm{B} 7-\mathrm{H} 4$ protein level in OSCC was higher than in normal mucosa. B7-H4 protein expression was associated with grade and nodal metastases [18]. B7-H4 expression was an independent prognostic factor and associated with poor overall survival [18].

\section{B7-H5 (VISTA)}

$\mathrm{B} 7-\mathrm{H} 5$ protein is a type I membrane protein $(50 \mathrm{kDa})$ encoded by the C10orf54 gene on chromosome 10 (locus 10q22.1). The B7-H5 protein has genes parallel to B7-1 ligand in 24\%. VISTA has two domains: IgC and IgV. VISTA transcription is regulated by the $\mathrm{p} 53$ protein. It is a control protein of the immune system. There are reports that the VISTA may function as a ligand and as a receptor [7, $8,19,69-72]$. VISTA was found in dendritic cells, T lymphocytes, monocytes, macrophages, bone marrow cells and granulocytes. It is not present on B or NK cells. VISTA has inhibitory effects on $T$ cell activity, proliferation, cytokine production, but not on B lymphocytes. Increased levels of VISTA proteins were observed in T lymphocytes in autoimmune diseases, cancer and generalized inflammation $[8,69]$. The presence of the $\mathrm{B} 7-\mathrm{H} 5$ protein expression has been demonstrated in gastrointestinal cancer [70-76], gastric cancer [74], lung cancer [7], pancreatic cancer [7, 75], myeloma [76] and head and neck cancer [72]. B7-H5 protein level in OSCC was higher than in normal mucosa and correlated with nodal metastases. B7-H5 expression was not an independent prognostic factor and was not associated with poor prognosis. The high level of VISTA was significantly correlated with PDL1, CTLA-4, IL13R $\alpha 2$ (interleukin-13 receptor subunit $\alpha 2$ ), PI-3K, p-STAT3 (signal transducer and activator of transcription 3), CD11b (integrin $\alpha b$ ) and CD33 (siglec-3/sialic acid binding Ig-like lectin 3) protein expression. High levels of VISTA and low levels of CD8 were associated with poor prognosis in the primary OSCC. These results indi- cate that VISTA may be a potential immunotherapeutic target in OSCC [19].

\section{B7-H6 and NKp30}

B7-H6 protein is a type I membrane protein encoded by the B7-H6 gene. This molecule has two domains: IgC and IgV. It binds to NKp30 molecule. B7-H6 protein was not found in healthy tissue, but was found on human monocytes and macrophages after LPS (lipopolysaccharides) and IFN-g stimulation. It was not observed on B or $T$ cells. It is responsible for the activation of the immune system $[7,77]$. The presence of the $\mathrm{B} 7-\mathrm{H} 6$ protein expression has been demonstrated in lung cancer [78], ovarian cancer [79], hepatocellular cancer [80], glioma [81], leukaemia, various sarcomas and renal cancer [82]. The literature documenting B7-H6 protein in OSCC is limited. In one of the studies, the percentage of common B7-H6 protein range was $48 \%$ and correlated with grade, overall survival and disease-free survival. The recurrence, differentiation and expression of $\mathrm{B} 7-\mathrm{H} 6$ protein were related to the prognosis [20].

NKp30 receptor is binding to $\mathrm{B} 7-\mathrm{H} 6$ protein. It is a type I protein encoded by the NCR3 / gene. NKp30 belongs to NCR family proteins (natural cytotoxicity receptors). This receptor is found on NK cells. NKp30 consists of the ectodomains: a membrane proximal stalk domain and a distal ligand-binding domain. The stalk domain can be important for binding to ligands. It has three isoforms: NKp30a, NKp30b and NKp30c. NKp30a and NKp3Ob have a stimulating effect and NKp30c has a suppressive effect. NKp30 recognizes B7-H6 antigens on the tumour. In a properly functioning system, NK cells destroy cancer cells directly via cytotoxicity or indirectly by cytokine secretion. The glycosylation status of NKp30 alters its binding affinity for B7-H6 [7, 83]. Expression of NKp30 protein was demonstrated in lung cancer (using flow cytometry) [78].

\section{B7-H7 and CD28H}

B7-H7 is encoded by the HHLA2 gene on chromosome 3 (locus 3q13.13). B7-H7 is a co-stimulation protein with three immunoglobulin-like domains (IgV-lgC-lgV). In contrast to other B7 family proteins, the expression of this protein is very low in healthy cells. It is present on monocytes, macrophages, B lymphocytes, mature dendritic cells, endothelial cells, epithelial cells and syncytiotrophoblast cells. There are probably two receptors of the $\mathrm{B} 7-\mathrm{H} 7-\mathrm{CD} 28 \mathrm{H}$ molecule with opposite functions. Binding of antigen-presenting cells (APC) to $\mathrm{CD} 28 \mathrm{H}$ stimulates $T$ cell proliferation and cytokine production. B7-H7 is likely to have a greater effect on NK cells (via the NKp30 receptor) than on T cells (interferon- $\gamma$, TNF- $\alpha$, IL-5, IL-10, IL-13, IL-17a, and IL-22). The presence of the $\mathrm{B} 7-\mathrm{H} 7$ protein expression has been demonstrated in various cancer cell lines: leukaemia, neuroblastoma, mela- 
noma, ovarian cancer, breast cancer, lung cancer, thyroid cancer, oesophagus cancer, gastric cancer, colon cancer, pancreatic cancer, hepatocellular cancer, bladder cancer and renal cancer $[7,8,84,85]$. The studies were carried out using immunohistochemistry [7, 9]. B7-H7 expression was with poor overall survival.

$\mathrm{CD} 28 \mathrm{H}$ is a receptor encoded by the TMIGD2 gene on chromosome 19 (locus 19p13.3). The TMIGD2 has genes parallel to $\mathrm{CD} 28$ receptor in $22.8 \%$. It binds to $\mathrm{B} 7-\mathrm{H} 7$. $\mathrm{CD} 28 \mathrm{H}$ is found in natural killer cells, APC cells and naive $T$ lymphocytes in peripheral blood. Binding to the receptor can trigger two actions: stimulation and suppression $[7,8,85]$.

\section{Conclusions}

The expression status of B7 proteins in OSCC cells remains unclear. There are not many scientific reports. The rapid increase in knowledge about the molecules of the B7/CD28 family opens new possibilities for the treatment and prognosis of patients. The data presented indicate the complexity of cellular and molecular processes related to the formation, development and invasion of oral cancer. Various mutations in genes encoding the B7 family and quantitative and functional changes in B7 proteins may be important in the prognosis of OSCC.

\section{Conflict of interest}

The authors declare no conflict of interest.

\section{References}

1. Ferlay J, Soerjomataram I, Dikshit R, et al. Cancer incidence and mortality worldwide: sources, methods and major patterns in GLOBOCAN 2012. Int J Cancer 2015; 136: E359-86.

2. Global Burden of Disease Cancer Collaboration. Global, regional, and national cancer incidence, mortality, years of life lost, years lived with disability, and disability-adjusted life-years for 29 Cancer Groups, 1990 to 2017: a systematic analysis for the global burden of disease study. JAMA Oncol 2019; 5: 1749-68.

3. Johnson NW, Jayasekara P, Amarasinghe AA. Squamous cell carcinoma and precursor lesions of the oral cavity: epidemiology and aetiology. Periodontology 2000 2011; 57: 19-37.

4. Starzyńska A, Sejda A, Adamska P, et al. Prognostic value of the PIK3CA, AKT, PTEN mutations in oral squamous cell carcinoma: literature review. Arch Med Sci https://doi. org/10.5114/aoms.2018.77859.

5. Zou W. Immunosuppressive networks in the tumour environment and their therapeutic relevance. Nat Rev Cancer 2005; 5: 263-74.

6. Song MK, Park BB, Uhm J. Understanding immune evasion and therapeutic targeting associated with PD-1/PD-L1 pathway in diffuse large B-cell lymphoma. Int J Mol Sci 2019; 20: 1326.

7. Ni L, Dong D. New B7 family checkpoints in human cancers. Mol Cancer Ther 2017; 16: 1203-11.

8. Schildberg FA, Klein SR, Freeman GJ, et al. Coinhibitory pathways in the B7-CD28 ligand-receptor family. Immunity 2016; 44: $955-72$.
9. Xiao Y, Freeman GJ. A new B7:CD28 family checkpoint target for cancer immunotherapy: HHLA2. Clin Cancer Res 2015; 21: 2201-3.

10. Liberati A, Altman DG, Tetzlaff J, et al. The PRISMA statement for reporting systematic reviews and meta-analyses of studies that evaluate health care interventions: explanation and elaboration. Ann Intern Med 2009; 151: 65-94.

11. Higgins JPT, Altman DG, Gøtzsche PC, et al. The Cochrane Collaboration's tool for assessing risk of bias in randomised trials. Br Med J 2011; 343: d5928.

12. Slim K, Nini E, Forestier D, et al. Methodological index for non-randomized studies (minors): development and validation of a new instrument. ANZ J Surg 2003; 73: 712-6.

13. Rah YC, Ahn JC, Jeon EH, et al. Low expression of CD $40 \mathrm{~L}$ in tumor-free lymph node of oral cavity cancer related with poor prognosis. Int I Clin Oncol 2018; 23: 851-9.

14. Zhang $S$, Zhang $X$, Yin $\mathrm{K}$, et al. Variation and significance of secretory immunoglobulin A, interleukin 6 and dendritic cells in oral cancer. Oncol Lett 2017; 13: 2297-303.

15. Dayan D, Salo T, Salo S, et al. Molecular crosstalk between cancer cells and tumor microenvironment components suggests potential targets for new therapeutic approaches in mobile tongue cancer. Cancer Med 2012; 1: 128-40.

16. Chen JT, Chen CH, Ku KL, et al. Glycoprotein B7-H3 overexpression and aberrant glycosylation in oral cancer and immune response. Proc Natl Acad Sci USA 2015; 112: 13057-62.

17. Zhang SS, Tang J, Yu SY, et al. Expression levels of B7-H3 and TLT-2 in human oral squamous cell carcinoma. Oncol Lett 2015; 10: 1063-8.

18. Wu L, Deng WW, Yu GT, et al. B7-H4 expression indicates poor prognosis of oral squamous cell carcinoma. Cancer Immunol Immunother 2016; 65: 1035-45.

19. Wu L, Deng WW, Huang CF, et al. Expression of VISTA correlated with immunosuppression and synergized with CD8 to predict survival in human oral squamous cell carcinoma. Cancer Immunol Immunother 2017; 66: 627-36.

20. Wang J, Jin X, Liu J, et al. The prognostic value of B7-H6 protein expression in human oral squamous cell carcinoma. J Oral Pathol Med 2017; 46: 766-72.

21. Xiao Y, Li H, Yang LL, et al. The expression patterns and associated clinical parameters of human endogenous retrovirus-H long terminal repeat-associating protein 2 and transmembrane and immunoglobulin domain containing 2 in oral squamous cell carcinoma. Dis Markers 2019; 7: 5421985.

22. Tatsumi T, Takehara T, Katayama K, et al. Expression of costimulatory molecules B7-1 (CD80) and B7-2 (CD86) on human hepatocellular carcinoma. Hepatology 1997; 25: 1108-14.

23. Shah R, Banks K, Patel A, et al. Intense expression of the B7-2 antigen presentation coactivator is an unfavorable prognostic indicator for differentiated thyroid carcinoma of children and adolescents. J Clin Endocrinol Metab 2002; 87: 4391-7.

24. Inman BA, Longo TA, Ramalingam S, et al. Atezolizumab: a PD-L1-blocking antibody for bladder cancer. Clin Cancer Res 2017; 23: 1886-90.

25. Wang L, Ma Q, Chen X, et al. Clinical significance of B7-H1 and B7-1 expressions in pancreatic carcinoma. World J Surg 2010; 34: 1059-65.

26. Chaux P, Moutet M, Faivre J, et al. Inflammatory cells infiltrating human colorectal carcinoma express HLA class II but not B7-1 and B7-2 costimulatory molecules of the T-cell activation. Lab Invest 1996; 74: 975-83.

27. Dong P, Ma L, Liu L, et al. CD86 /CD206+ diametrically polarized tumor-associated macrophages, predict hepatocellular carcinoma patient prognosis. Int J Mol Sci 2016; 17: 320. 
28. Norton SD, Zuckerman L, Urdahl KB, et al. The CD28 ligand, B7, enhances IL-2 production by providing a costimulatory signal to T cells. J Immunol 1992; 149: 1556-61.

29. Sharpe AH, Freeman GJ. The B7-CD28 superfamily. Nat Rev Immunol 2002; 2: 116-26.

30. Kämmerer PW, Toyoshima T, Schöder F, et al. Association of T-cell regulatory gene polymorphisms with oral squamous cell carcinoma. Oral Oncol 2010; 46: 543-8.

31. Burr JS, Savage ND, Messah GE, et al. Cutting edge: distinct motifs within CD28 regulate $T$ cell proliferation and induction of Bcl-XL. J Immunol 2001; 166: 5331-5.

32. Bharti V, Mohanti BK, Das SN. Functional genetic variants of CTLA-4 and risk of tobacco-relate oral carcinoma in high-risk North Indian population. Hum Immunol 2013; 74: 348-52.

33. Pastuszak-Lewandoska D, Sewerynek E, Domańska D, et al. CTLA-4 gene polymorphisms and their influence on predisposition to autoimmune thyroid diseases (Graves' disease and Hashimoto's thyroiditis). Arch Med Sci 2012; 8: 415-21.

34. Okazaki T, Wang J. PD-1/PD-L pathway and autoimmunity. Autoimmunity 2005; 38: 353-7.

35. Okazaki T, Honjo T. PD-1 and PD-1 ligands: from discovery to clinical application. Int Immunol 2007; 19: 813-24.

36. Chan DV, Gibson HM, Aufiero BM, et al. Differential CTLA-4 expression in human CD4+ versus CD8+ T cells is associated with increased NFAT1 and inhibition of CD4+ proliferation. Genes Immun 2014; 15: 25-32.

37. Yang H, Bueso-Ramos C, DiNardo C, et al. Expression of PDL1, PD-L2, PD-1 and CTLA4 in myelodysplastic syndromes is enhanced by treatment with hypomethylating agents. Leukemia 2014; 28: 1280-8.

38. Huang PY, Guo SS, Zhang Y, et al. Tumor CTLA-4 overexpression predicts poor survival in patients with nasopharyngeal carcinoma. Oncotarget 2016; 7: 13060-8.

39. Montler R, Bell RB, Thalhofer C, et al. OX40, PD-1 and CTLA-4 are selectively expressed on tumor-infiltrating $T$ cells in head and neck cancer. Clin Transl Immunol 2016; 5: e70.

40. Moreira G, Fulgęncio LB, De Mendonca EF, et al. T regulatory cell markers in oral squamous cell carcinoma: relationship with survival and tumor aggressiveness. Oncol Lett 2010; 1: 127-32.

41. Cao Y, Cao T, Zhao W, et al. Expression of B7-H2 on $\mathrm{CD}^{+} \mathrm{T}$ cells in colorectal cancer microenvironment and its clinical significance. Int Immunopharmacol 2018; 56: 128-34.

42. Leitner J, Klauser C, PickI WF, et al. B7-H3 is a potent inhibitor of human T-cell activation: no evidence for $\mathrm{B} 7-\mathrm{H} 3$ and TREML2 interaction. Eur J Immunol 2009; 39: 1754-64.

43. Dong P, Xiong Y, Yeu J, et al. B7H3 as a promoter of metastasis and promising therapeutic target. Front Oncol 2018; 8: 264.

44. Luo D, Xiao H, Dong J, et al. B7-H3 regulates lipid metabolism of lung cancer through SREBP1- mediated expression of FASN. Biochem Biophys Res Commun 2017; 482: 1246-51.

45. Xu L, Ding X, Tan H, Qian J. Correlation between B7-H3 expression and matrix metalloproteinases 2 expression in pancreatic cancer. Cancer Cell Int 2014; 13: 81.

46. Maeda N, Yoshimura K, Yamamoto S, et al. Expression of B7$\mathrm{H} 3$, a potential factor of tumor immune evasion in combination with the number of regulatory $T$ cells, affects against recurrence-free survival in breast cancer patients. Ann Surg Oncol 2014; 21: S546-54.

47. Zhang J, Liu L, Han S, et al. B7-H3 is related to tumor progression in ovarian cancer. Oncol Rep 2017; 38: 2426-34.
48. Brunner A, Hinterholzer S, Riss P, et al. Immunoexpression of B7-H3 in endometrial cancer: relation to tumor T-cell infiltration and prognosis. Gynecol Oncol 2012; 124: 105-11.

49. Zang X, Thompson RH, Al-Ahmadie HA, et al. B7-H3 and B7X are highly expressed in human prostate cancer and associated with disease spread and poor outcome. Proc Natl Acad Sci USA 2007; 104: 19458-63.

50. Wang G, Wu Z, Wang Y, et al. Therapy to target renal cell carcinoma using 1311-labeled B7-H3 monoclonal antibody. Oncotarget 2016; 6: 24888-98.

51. Wu CP, Jiang JT, Tan M, et al. Relationship between co-stimulatory molecule B7-H3 expression and gastric carcinoma histology and prognosis. World J Gastroenterol 2006; 12: 457-9.

52. Mao Y, Sun J, Wang WP, et al. Clinical significance of costimulatory molecule B7-H3 expression on CD3(+) T cells in colorectal carcinoma. Chin Med J (Engl) 2013; 126: 3035-8.

53. Liu CL, Zang XX, Huang $\mathrm{H}$, et al. The expression of $\mathrm{B} 7-\mathrm{H} 3$ and $\mathrm{B} 7-\mathrm{H} 4$ in human gallbladder carcinoma and their clinical implications. Eur Rev Med Pharmacol Sci 2016; 20: 4466-73.

54. Wang F, Wang G, Liu T, et al. B7-H3 was highly expressed in human primary hepatocellular carcinoma and promoted tumor progression. Cancer Invest 2014; 32: 262-71.

55. Mao L, Fan TF, Wu L, et al. Selective blockade of B7-H3 enhances antitumour immune activity by reducing immature myeloid cells in head and neck squamous cell carcinoma. J Cell Mol Med 2017; 21: 2199-210.

56. Flem-Karlsen K, Fodstad $\varnothing$, Tan M, et al. B7-H3 in cancerbeyond immune regulation B7-H3 PI3K NF- kappaB. Trends Cancer 2018; 4: 401-4.

57. Chen X, Wang L, Wang W, et al. B7-H4 facilitates proliferation of esophageal squamous cell carcinoma cells through promoting interleukin-6/signal transducer and activator of transcription 3 pathway activation. Cancer Sci 2016; 107: 944-54.

58. Cho YA, Yoon HJ, Lee JI, et al. Relationship between the expressions of PD-L1 and tumor-infiltrating lymphocytes in oral squamous cell carcinoma. Oral Oncol 2011; 47: 1148-53.

59. Xu Y, Zhu S, Song M, et al. B7-H4 expression and its role in interleukin-2/interferon treatment of clear cell renal cell carcinoma. Oncol Lett 2014; 7: 1474-8.

60. Li ZY, Zhang XH, Chen Y, et al. Clinical significance of B7$\mathrm{H} 4$ expression in matched non-small cell lung cancer brain metastases and primary tumors. Onco Targets Ther 2013; 6: 869-75.

61. Simon I, Katsaros D, Rigault de la Longrais I, et al. B7-H4 is over-expressed in early-stage ovarian cancer and is independent of CA125 expression. Gynecol Oncol 2007; 106: 334-41.

62. Liu W, Shibata K, Koya Y, et al. B7-H4 overexpression correlates with a poor prognosis for cervical cancer patients. Mol Clin Oncol 2014; 2: 219-25.

63. Chen LJ, Sun J, Wu HY, et al. B7-H4 expression associates with cancer progression and predicts patient's survival in human esophageal squamous cell carcinoma. Cancer Immunol Immunother 2011; 60: 1047-55.

64. Geng Y, Wang H, Lu C, et al. Expression of costimulatory molecules B7-H1, B7-H4 and Foxp3+ Tregs in gastric cancer and its clinical significance. Int J Clin Oncol 2015; 20: 273-81.

65. Liang $M$, Li J, Wang D, et al. T-cell infiltration and expressions of T lymphocyte co-inhibitory B7-H1 and B7-H4 molecules among colorectal cancer patients in northeast China's Heilongjiang province. Tumour Biol 2014; 35: 55-60.

66. Chen Y, Sun J, Zhao H, et al. The coexpression and clinical significance of costimulatory molecules $\mathrm{B} 7-\mathrm{H} 1, \mathrm{~B} 7-\mathrm{H} 3$, and 
B7-H4 in human pancreatic cancer. Onco Targets Ther 2014; 7: 1465-72.

67. Zhu J, Chu BF, Yang YP, et al. B7-H4 Expression is associated with cancer progression and predicts patient survival in human thyroid cancer. Asian Pac J Cancer Prev 2013; 14: 3011-15.

68. Quandt D, Fiedler E, Boettcher D, et al. B7-H4 expression in human melanoma: its association with patients' survival and antitumor immune response. Clin Cancer Res 2011; 17: 3100-11.

69. Flies DB, Han X, Higuchi T, et al. Coinhibitory receptor PD-1H preferentially suppresses CD4+ T cell-mediated immunity. J Clin Invest 2014; 124: 1966-75.

70. Lines JL, Pantazi E, Mak J, et al. VISTA is an immune checkpoint molecule for human T cells. Cancer Res 2014; 74: 1924-32.

71. Kondo Y, Ohno T, Nishii N, et al. Differential contribution of three immune checkpoint (VISTA, CTLA-4, PD-1) pathways to antitumor responses against squamous cell carcinoma. Oral Oncol 2016; 57: 54-60.

72. Deng WW, Wu L, Sun ZJ. Co-inhibitory immune checkpoints in head and neck squamous cell carcinoma. Oral Dis 2018; 24: 120-3.

73. Zhao Q, Hu F, Xiao Z, et al. Comprehensive molecular profiling of the B7 family in gastrointestinal cancer. Cell Prolif 2018; 51: e12468.

74. Oliveira P, Carvalho J, Rocha S, et al. Dies1/VISTA expression loss is a recurrent event in gastric cancer due to epigenetic regulation. Sci Rep 2016; 6: 34860.

75. Byers JT, Paniccia A, Kaplan J, et al. Expression of the novel costimulatory molecule B7-H5 in pancreatic cancer. Ann Surg Oncol 2015; 22: S1574-9.

76. Spicka I, Mateos MV, Redman K, et al. An overview of the VISTA trial: newly diagnosed, untreated patients with multiple myeloma ineligible for stem cell transplantation. Immunotherapy 2011; 3: 1033-40.

77. Flajnik MF, Tlapakova T, Criscitiello MF, et al. Evolution of the B7 family: co-evolution of B7H6 and NKp30, identification of a new B7 family member, B7H7, and of B7's historical relationship with the MHC. Immunogenetics 2012; 68: 571-90.

78. Zhang X, Zhang G, Qin Y, et al. B7-H6 expression in nonsmall cell lung cancers. Int J Clin Exp Pathol 2014; 7: 6936-42.

79. Zhou Y, Xu Y, Chen L, et al. B7-H6 expression correlates with cancer progression and patient's survival in human ovarian cancer. Int J Clin Exp Pathol 2015; 8: 9428-33.

80. Chen L, Feng J, Xu B, et al. Expression of B7-H6 expression in human hepatocellular carcinoma and its clinical significance. Cancer Cell Int 2018; 18: 126.

81. Che F, Xie X, Wang L, et al. B7-H6 expression is induced by lipopolysaccharide and facilitates cancer invasion and metastasis in human gliomas. Int Immunopharmacol 2018; 59: 318-27.

82. Brandt CS, Baratin M, Yi EC, et al. The B7 family member B7$\mathrm{H} 6$ is a tumor cell ligand for the activating natural killer cell receptor NKp30 in humans. J Exp Med 2009; 206: 1495-503.

83. Koch J, Steinle A, Watzl C, et al. Activating natural cytotoxicity receptors of natural killer cells in cancer and infection. Trends Immunol 2013; 34: 182-91.

84. Janakiram M, Chinai JM, Fineberg S, et al. Expression, clinical significance, and receptor identification of the newest B7 family member HHLA2 protein. Clin Cancer 2015; 21: 2359-66.

85. Tian Y, Sun Y, Gao F, et al. CD28H expression identifies resident memory $C D 8+T$ cells with less cytotoxicity in human peripheral tissues and cancers. Oncoimmunology 2018; 8: e1538440. 